\title{
Eucalyptus ESTs corresponding to the enzyme glutamine synthetase and the protein D1, sites of action of herbicides that cause oxidative stress
}

\author{
Edivaldo Domingues Velini ${ }^{1}$, Maria Lúcia Bueno Trindade ${ }^{1}$, Elza Alves ${ }^{1}$, Ana Catarina Catâneo ${ }^{2}$, \\ Celso Luis Marino ${ }^{3}$, Ivan de Godoy Maia ${ }^{3}$, Edson Seizo Mori ${ }^{4}$, Edson Luiz Furtado ${ }^{5}$, \\ Iraê Amaral Guerrini ${ }^{6 \#}$ and Carlos Frederico Wilcken ${ }^{7}$ \\ ${ }^{1}$ Universidade Estadual Paulista "Júlio de Mesquita Filho", Faculdade de Ciências Agrárias, \\ Fazenda Experimental Lageado, Laboratório de Matologia, Botucatu, SP, Brazil. \\ ${ }^{2}$ Universidade Estadual Paulista "Júlio de Mesquita Filho", Instituto de Biociências, \\ Laboratório de Xenobióticos, Botucatu, SP, Brazil. \\ ${ }^{3}$ Universidade Estadual Paulista "Júlio de Mesquita Filho", Instituto de Biociências, \\ Laboratório de Genética, Botucatu, SP, Brazil. \\ ${ }^{4}$ Universidade Estadual Paulista "Júlio de Mesquita Filho", Faculdade de Ciências Agrárias, \\ Fazenda Experimental Lageado, Laboratório de Melhoramento Vegetal, Botucatu, SP, Brazil. \\ ${ }^{5}$ Universidade Estadual Paulista "Júlio de Mesquita Filho", Faculdade de Ciências Agrárias, \\ Fazenda Experimental Lageado, Laboratório de Fitopatologia, Botucatu, SP, Brazil. \\ ${ }^{6}$ Universidade Estadual Paulista "Júlio de Mesquita Filho", Faculdade de Ciências Agrárias, \\ Fazenda Experimental Lageado, Laboratório de Solos, Botucatu, SP, Brazil. \\ ${ }^{7}$ Universidade Estadual Paulista "Júlio de Mesquita Filho", Faculdade de Ciências Agrárias, \\ Fazenda Experimental Lageado, Laboratório de Entomologia, Botucatu, SP, Brazil.
}

\begin{abstract}
This work was aimed at locating Eucalyptus ESTs corresponding to the GS enzyme (Glutamine Synthetase, $\mathrm{EC}=6.3 .1 .2$ ) and to the $\mathrm{D} 1$ protein, which are directly related to resistance to herbicides that promote oxidative stress. Glutamine Synthetase corresponds to the site of action of the herbicide glufosinate. Herbicides that belong to groups such as ureas, uracils, triazines and triazinones act on the D1-Qb complex (receptor of electrons from the Photosystem II) by inactivating it. The clusters EGEQRT3302E01.g, EGEQRT3001F12.b; EGEZLV1203B04.g; EGBGFB1211H06.g and EGEZLV1205F09.g enclosed complete sequences (with 356 amino acids) of the Glutamine Synthetase enzyme. The cluster EGEQSL1054G06.g is a consensus of four reads and enclosed a complete sequence of D1 Protein (with 353 amino acids). The comparison of the sequences of Protein D1 from different species showed that the substitutions of serine $(S)$ by glycine $(G)$ or serine $(S)$ by threonine $(T)$ at the position 264 could produce plants resistant to herbicides that act on electron flow on Photosystem II. The sequence of amino acids corresponding to the cluster EGEQSL1054G06.g had a serine in position 264 indicating sensitivity of the Eucalyptus plants to herbicides that act on this site.
\end{abstract}

Key words: Eucalyptus, glutamine synthetase, D1 protein, herbicide.

Received: May 28, 2004; Accepted: June 8, 2005.

\section{Introduction}

Four herbicide action mechanisms are known to cause plant death by promoting oxidative stress: interference with the flow of electrons of Photosystem I, or Photosystem II, and action on the enzymes protoporphyrinogen

Send correspondence to Edivaldo Domingues Velini. Universidade Estadual Paulista, Faculdade de Ciências Agrárias, Fazenda Experimental Lageado, Laboratório de Matologia, 18603-970 Botucatu, SP, Brazil. E-mail: velini@fca.unesp.br. \#Supported by CNPq.
IX oxidase (Protox or PPO, E.C. 1.3.3.4), or Glutamine Synthetase (GS, EC = 6.3.1.2). Oxidative stress is associated with the production of highly reactive free radicals. These radicals are very effective in oxidizing lipids from cell membranes.

This work aimed at studying Eucalyptus ESTs related to the action of herbicides on the flow of electrons in Photosystem II and the synthesis of glutamine. The action of diquat and paraquat is related to the electron flow deviation in photosystem I but their effects are not directly asso- 
ciated to the interaction with enzymes or proteins; for this reason, they should not be included in this work. The enzyme Protox, highly relevant for herbicide action and physiological modifications in plants, has been discussed in a separate paper.

Variability in the levels of action of the herbicides that act upon the sites addressed in this paper depends on characteristics of the site itself (amino acids sequence in the proteins and expression levels), as well as the plants ability to inactivate the free radicals produced, which actually generate plant intoxication. Variability in absorption and translocation capacity (even at small distances) is also an important factor that conditions the effectiveness of any compound with herbicidal action. The study of Eucalyptus ESTs related to detoxifying systems, which are important in defining the levels of action of herbicides that cause oxidative stress, was already carried out by Alves et al. (2005).

GS takes part in the glutamine synthesis and glufosinate is the only commercially available herbicide that acts on this enzyme. The death of plants intoxicated by glufosinate is not caused by a lack of glutamine or glutamate, but by the excess of non-incorporated ammonia. Working with GS is quite interesting, since glufosinate is applied in postemergence (compatible with reduced tillage in foresting areas), acting on grasses and broad-leaf plants. In addition, this compound is produced by fermentation and shows low toxicity and high safety to environment. The mechanism of action and the genes involved in resistance to this herbicide have been described by Kishi and Ishisuka (1992), Baron et al. (1994), Baron et al. (1994a), Downs et al. (1994), Altenburger et al. (1995), Bridges and Hess (2002) and Thill (2002).

White et al. (1990), Schwartz et al. (1996) and Bridges and Hess (2002) presented two sequences that code for the production of the enzyme phosphinothricin-Nacetyltransferase, which has the ability to inactivate glufosinate: the PAT gene from Streptomyces hygroscopicus and the BAR gene from Streptomyces viridochromogenes. However, no references have been found on the variability of the GS enzyme that could be related to the glufosinate herbicide selectivity. In addition, the information presented indicate the GS potential for changing the production of glutamate and, consequently, of porphyrins in plants.

According to Thill (2002), the sequences that code for the production of the enzyme phosphinothricin-Nacetyltransferase have been introduced or are in the process of being introduced into a total of 22 crops, among which are soybean, beet, canola, rice, and corn. No references have been found on Eucalyptus species that would have received the sequence. The plants or crops into which the enzyme production has been incorporated become resistant to the herbicide glufosinate.

With regard to interference with the electron flow in the Photosystem II, according to van Rensen (1982), Itoh and Iwaki (1989), Judson and Rowson (1989), Fuerst et al.
(1991), Giardi et al. (1992), Arnaud et al. (1994), Egner et al. (1996), Weller (1997), Huppatz (1996), Hess (2000) and Weller (2002) the action results from binding the herbicides to the D1 protein, preventing the formation of the D1-QB complex, a receptor of electrons from this photosystem. According to those authors, the D1 protein, which is the main component that determines the functionality of the complex, is genetically coded in the chloroplast. The change of a single amino acid in the protein's sequence could modify the photosynthetic efficiency and confer resistance to several herbicides that inhibit the electron flow in Photosystem II (Examples: ureas, uracils, triazines and triazinones). Some of these herbicides show a high potential for use in Eucalyptus because of their control spectrum, low cost, long residual effect, preemergence and early postemergence action, low toxicity, low environmental risk, and easy transportation through the litter fall, in rain water. The herbicides diuron and ametryn are examples of compounds that present the above-mentioned characteristics, and belong to the urea and triazine groups, respectively.

This work was aimed at locating Eucalyptus ESTs corresponding to GS enzymes (Glutamine Synthetase, $\mathrm{EC}=6.3 .1 .2)$ and to the $\mathrm{D} 1$ protein, which are directly related to the action or resistance to herbicides, synthesis of porphyrins and photosynthetic activity in plants.

\section{Material and Methods}

This work resulted from an analysis of the information bank produced in the first stage of the Eucalyptus Genome Project (Projeto Genoma do Eucalyptus - FORESTs), jointly developed by FAPESP and a consortium of four companies in the forestry industry (Duratex, Ripasa, Suzano, and VCP) and executed with the participation of 20 laboratories from the State of São Paulo associated with the AEG network (https:forests.esalq.usp.br). In all, 123,889 reads constructed from expressed sequence tags (ESTs) of cDNA libraries, mainly derived from Eucalyptus grandis tissues, were obtained. The tissues were removed from different organs of plants submitted to different growing conditions. The makeup and coding of the libraries are described in Table 1.

The search for enzyme sequences corresponding to GS enzyme and D1 protein was performed using the BLAST tool (Altschud et al., 1997). The amino acid sequences for the GS enzyme and the D1 protein, described for different plant species, were compared with the information from the FORESTs project database using the "tBLASTn" option, allowing the identification of Clusters associated with them. Only Clusters effectively aligned with the amino acid sequences were selected, using an e-value $<$ e-70 as a selection criterion.

The nucleotide sequences of the selected Clusters were compared with the NCBI (National Center Biotechnology Information) and the geneBank amino acid se- 
quence databases after translation in all possible frames. The procedure allowed to confirm the alignment with sequences of the GS enzyme or the D1 protein from different plant species, to find the translation frame for the cluster

Table 1 - Codes and source tissues of cDNA libraries approved by the FORESTS project.

\begin{tabular}{|c|c|}
\hline Code & Tissues / growing condition \\
\hline BK1 & $\begin{array}{l}\text { Bark, sapwood, heartwood, and pith of 8-year old } E \text {. } \\
\text { grandis trees }\end{array}$ \\
\hline CL1 & E. grandis calluses formed in the dark \\
\hline CL2 & E. grandis calluses formed in the light \\
\hline FB1 & Buds, flowers and fruits \\
\hline LV1 & Seedling leaves \\
\hline LV2 & $\begin{array}{l}\text { Leaves from trees efficient and poorly efficient in } \\
\text { phosphorus and boron utilization }\end{array}$ \\
\hline LV3 & $\begin{array}{l}\text { Leaves colonized with the caterpillar Thyrinteina sp. for } \\
7 \text { days }\end{array}$ \\
\hline RT3 & Nursery seedling roots \\
\hline RT6 & Roots of trees resistant and susceptible to frost \\
\hline SL1 & $\begin{array}{l}\text { E. grandis seedlings grown in the dark and exposed to light } \\
\text { for } 3 \mathrm{~h} \text { prior to RNA extraction }\end{array}$ \\
\hline SL4 & E. globulus seedlings grown in the dark \\
\hline SL5 & E. saligna seedlings grown in the dark \\
\hline SL6 & E. urophylla seedlings grown in the dark \\
\hline SL7 & E. grandis seedlings grown in the dark \\
\hline SL8 & E. camaldulensis seedlings grown in the dark \\
\hline $\mathrm{ST} 2$ & $\begin{array}{l}\text { Stems of six-month old seedlings susceptible to water } \\
\text { deficit }\end{array}$ \\
\hline ST6 & Stems of seedlings susceptible to water deficit \\
\hline ST7 & Stems of trees resistant and susceptible to frost \\
\hline WD2 & E. grandis wood \\
\hline
\end{tabular}

and to obtain values of identity percents and similarity probability values (e-value) for the alignments.

Based on the translation frame that produced the best alignments and using the software GENERUNR, the nucleotide sequence corresponding to the clusters was translated into amino acids for the identification and analysis of Open Read Frames. The software CLUSTAL was used to align the amino acid sequences corresponding to the identified ORFs and the amino acid sequences of different plant species (with e-value $<$ e-70 as previously described).

\section{Results and Discussion}

The sequences corresponding to the BAR and PAT genes presented by White et al. (1990) and Schwartz et al. (1996) were not found in the ESTs database of the FORESTs project, indicating that their incorporation to genotypes of commercial interest should be done from external gene sources. The development of glufosinate-tolerant clones is an excellent opportunity for simplifying and reducing weed control costs in Eucalyptus, but the incorporation of BAR or PAT genes can only be done by producing transgenic clones.

With regard to the GS (Glutamine Synthetase), twelve clusters were identified showing high similarity with a sequence corresponding to the enzyme, obtained from Arabidopsis thaliana. It were observed e-values ranging from 0.0 to $4 \mathrm{e}-75$ (Table 2). Nine of the clusters corresponded to consensual sequences from 2 to 106 reads. Three of the clusters were single reads. The nucleotide sequences of the clusters were compared with the NCBI (National Center Biotechnology Information) and the geneBank amino acid sequence databases after translation in all possible frames and the results are presented in Table 3.

Table 2 - Clusters from Eucalyptus, identified through the tBlastn tool, which showed homology with the GS enzyme (Glutamine Synthetase, $\mathrm{EC}=6.3 .1 .2)$ and with the Protein D1.

\begin{tabular}{|c|c|c|c|c|c|c|}
\hline Enzyme protein & Species & Accession & Cluster & e-value & N. of reads & N. of nucleotides \\
\hline \multirow[t]{12}{*}{ GS } & Arabidopsis thaliana & AAM67495 & EGEZLV1205F09.g & e-177 & 49 & 1787 \\
\hline & Arabidopsis thaliana & AAM67495 & EGEQRT3302E01.g & 0.0 & 45 & 1290 \\
\hline & Arabidopsis thaliana & AAM67495 & EGEZLV1203B04.g & 0.0 & 38 & 1433 \\
\hline & Arabidopsis thaliana & AAM67495 & EGEQRT3001F12.b & 0.0 & 106 & 2376 \\
\hline & Arabidopsis thaliana & AAM67495 & EGBFB1211H06.g & 0.0 & 5 & 1383 \\
\hline & Arabidopsis thaliana & AAM67495 & EGEZSL8047G03.g & e-128 & 7 & 836 \\
\hline & Arabidopsis thaliana & AAM67495 & EGUTST6223H02.g & e-117 & 3 & 834 \\
\hline & Arabidopsis thaliana & AAM67495 & EGCCFB1220G03.g & e-100 & 1 & 404 \\
\hline & Arabidopsis thaliana & AAM67495 & EGJFST2005F09.g & $6 e-99$ & 9 & 1413 \\
\hline & Arabidopsis thaliana & AAM67495 & EGCECL2011D08.g & $2 \mathrm{e}-97$ & 1 & 789 \\
\hline & Arabidopsis thaliana & AAM67495 & EGEPST2215E04.g & $8 \mathrm{e}-80$ & 1 & 788 \\
\hline & Arabidopsis thaliana & AAM67495 & EGEQRT3104B08.g & $4 \mathrm{e}-75$ & 2 & 1204 \\
\hline \multirow[t]{2}{*}{ D1 } & Arabidopsis thaliana & NP_051039 & EGEQSL1054G06.g & 0.0 & 4 & 1156 \\
\hline & Lactuca sativa & AAL28074 & EGEQSL1054G06.g & 0.0 & 4 & 1156 \\
\hline
\end{tabular}


Only values of e-value superior to e-70 were observed by aligning the amino acid sequence of the cluster "EGE PST2215E04.g" with sequences of GS from literature. The results observed for all the other eleven clusters are presented in Table 3. Due to the high number alignments with e-values smaller than e-70, they were counted and the numbers are presented in the fourth column of Table 3. For five clusters it was possible to identify ORFs lengthening 356 amino acids and corresponding to GS sequences from literature.

The results of the alignment of the five longest sequences from Eucalyptus and sequences from eight other species are presented in Figure 1. If the same amino acid was observed in a certain position for all studied sequences, the column was marked with an asterisk enabling the identification of several conserved regions with lengths ranging from one to twelve amino acids. Results indicated that it is viable develop specific primers to be used in additional sequencing of the enzyme Glutamine Synthetase aiming to find promoters and SNPs to induce different levels of expression of the gene or activity of GS and, as a result, plants of Eucalyptus exhibiting higher or lower levels of sensitivity to glufosinate. The results also showed that the clusters EGEQRT3302E01.g, EGEQRT3001F12.b; EGEZLV12 03B04.g; EGBGFB1211H06.g and EGEZLV1205F09.g enclosed complete sequences of the Glutamine Synthetase enzyme. It must be pointed out that the 267 reads related to GS were present in almost all libraries, indicating the expression of this gene in different tissues and conditions.

Information relative to the cluster EGEQSL1054 G06.g with a high homology with amino acid sequences corresponding to the D1 protein obtained from the species Arabidopsis thaliana and Lactuca sativa are presented in Table 2. The cluster is a consensus of four reads from calluses and seedlings libraries. The nucleotide sequences of the clusters were compared with the NCBI (National Cen- ter Biotechnology Information) and the geneBank amino acid sequence databases after translation in all possible frames and it was obtained a total of 582 alignments with e-value smaller than e-70. The results of the alignment of the Eucalyptus sequence with sequences from fourteen other species are presented in Table 4. For three of these fourteen species, it was possible to find sequences corresponding to Protein D1 from plants susceptible or resistant to herbicides acting on the flow of electrons in Photosystem II. The translation of the nucleotide sequence of the cluster EGEQSL1054G06.g using the frame "+2" allowed to identify an ORF lengthening 353 amino acids and corresponding to Protein D1 sequences from literature.

The alignment of the sequences using CLUSTALX indicated an almost complete homology among the sequences from different species. It was possible to identify conserved regions lengthening from eleven to 83 amino acids. In effect, differences among the amino acid sequences were observed only at the positions $11,24,78,155,238$, 264, 281 and 346-353.

The comparison of the sequences of Protein D1 showed that the position 264 is the only one in which substitutions of amino acids produced plants resistant to herbicides (Figure 2). The substitutions of serine (S) by glycine (G) produced resistant plants of Amaranthus powelli and Bromus tectorum. In Nicotiana tabacum, resistance to herbicides resulted from the substitution of serine (S) by threonine (T). It must be highlighted that the sequence of amino acids corresponding to the cluster EGEQSL1054G06.g had a serine in position 264 indicating sensitivity of the Eucalyptus plants to herbicides that act on this site.

It is important to point out that the Protein D1 was completely sequenced and presents a high level of preservation. Considering that D1 Protein is encoded in chloroplasts and that changes in the amino acid sequences can

Table 3 - Translation frames for the nucleotide sequence of the clusters, minimum and maximum valures of e-value and sizes of the ORFs corresponding to the GS enzyme (Glutamine Synthetase, $\mathrm{EC}=6.3 .1 .2$ ).

\begin{tabular}{|c|c|c|c|c|c|}
\hline \multirow[t]{2}{*}{ Cluster } & \multirow[t]{2}{*}{ Frame } & \multirow{2}{*}{$\begin{array}{l}\text { Size of the ORF } \\
\text { correspondisng to GS }\end{array}$} & \multirow{2}{*}{$\begin{array}{l}\text { Number of } \\
\text { sequences }^{(1)}\end{array}$} & \multicolumn{2}{|c|}{ e-value } \\
\hline & & & & Minimum & Maximum \\
\hline EGEQRT3302E01.g & +1 & 356 & 282 & 0.0 & e-70 \\
\hline EGEQRT3001F12.b & +3 & 356 & 288 & e-177 & $e-70$ \\
\hline EGEZLV1203B04.g & +3 & 356 & 296 & 0.0 & e-70 \\
\hline EGBGFB1211H06.g & +1 & 356 & 295 & 0.0 & e-70 \\
\hline EGEZLV1205F09.g & +2 & 356 & 288 & 0.0 & e-70 \\
\hline EGJFST2005F09.g & +3 & 303 & 135 & e-105 & e-70 \\
\hline EGEZSL8047G03.g & +2 & 258 & 140 & e-110 & e-70 \\
\hline EGUTST6223H02.g & +1 & 240 & 142 & e-104 & $e-70$ \\
\hline EGEQRT3104B08.g & +2 & 193 & 76 & $9 \mathrm{e}-80$ & e-70 \\
\hline EGCCFB1220G03.g & +1 & 163 & 151 & e-104 & e-70 \\
\hline EGCECL2011D08.g & +2 & 148 & 74 & $3 e-78$ & e-70 \\
\hline
\end{tabular}

${ }^{(1)}$ Number of amino acid sequences from literature aligning with sequences corresponding to the clusters from Eucalyptus. 


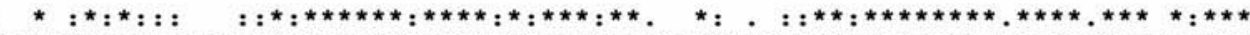
EGEQRT3302E01.g MSLLSDLLNLNLSDTTEKVIAEYIWIGGSGMDLRSKARTLNGPVSDPSKLPKWNYDGSSTNQAPGEDSEVILYPQ EGEQRT $3001 \mathrm{~F} 12$.b MSLLSDLLNLNLSDTTEKIIAEYIWIGGSGMDLRSKARTLNGPVSDPAKLPRWNYDGSSTGQAPGEDSEVILYPQ EGEZLV1203B04.g MSLLSDLVNLNLSDCTEKIIAEYIWIGGSGMDMRSKARTF PGPVNDPSKLPKWNYDGSSTNQAPGEDSEVILYPQ EGBGFB $1211 \mathrm{H} 06 . \mathrm{g}$ MSALNDLLNFDLFDYTDKIIAEYIWIGGSGIDMRSKARTLRGPVTDPAKLPKWNYDGSSTDQAPGHDSEVILYPQ EGEZLV1205F09.g INRLENLLNLDVTPYTDKIIAEYIWIGGSGIDLRSKSRTISRPVEHPSELPKWNYDGSSTGQAPGEDSEVILYPQ

A.thaliana MSLLADLVNLDISDNSEKIIAEYIWVGGSGMDMRSKARTLPGPVTDPSKLPKWNYDGSSTGQAPGQDSEVILYPQ G.max MSLLSDLINLNLSDTTEKVIAEYIWIGGSGMDLRSKARTLPGPVSDPSELPKWNYDGSSTGQAPGEDSEVILYPQ L. sativa MALLSDLVNLDLSS ITDKI IAEYIWIGGSGMDLRSKARTLSGPVSDPSELPKWNYDGSSTGQAPGEDSEVIIYPQ N. tabacum MAHLSDLVNLNLSDSTQKIIAEYIWIGGSGMDVRSKARTLSGPVDDPSKLPKWNYDGSSTGQAPGEDSEEILYPQ R.sativus MSLLTDLINLNLSETTDKIIAEYIWVGGSGMDMRSKARTLPGPVSDPSELPKWNYDGSSTGOAPGEDSEVILYPO O.sativa MANLTDLVNLNLSDCSDKIIAEYIWVGGSGIDLRSKARTVKGPITDVSQLPKWNYDGSSTGQAPGEDSEVILYPQ Z.mays MACLTDLVNLNLSDTTEKIIAEYIWIGGSGMDLRSKARTLPGPVTDPSKLPKWNYDGSSTGQAPGEDSEVILYPQ

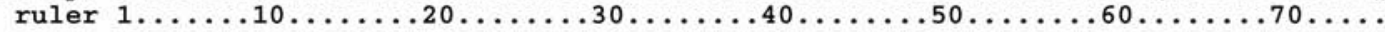

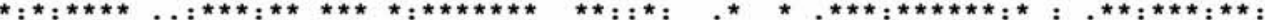
EGEQRT $3302 \mathrm{E} 01 . \mathrm{g}$ AIFKDPFRRGNNILVMCDAYTPAGEPIPTNKRHAAAKVFSHPDVLAEEPWYGIEQEYTLLQRDVKWPIGWPLGGY EGEQRT $3001 \mathrm{~F} 12 \mathrm{~b}$ AIFKDPFRRGNNILVMCDAYTPAGEPIPTNKRCDAAKIFSQPDVVAEVPWYGIEQEYTLLQKNVRWPLGWPVGGY EGEZLV12 03B04.g AIFKDPFRGGNNILVMCDAYTPGGQPIPTNKRCAAAKIFSHPNVVVEEPWYGLEQEYTLLQKDVKWPLGWPVGGF EGBGFB1211 06 .g AVFRDPFRRGSNILVMCDAYTPAGEPIPTNKRFNAAKVFSDPHVVAEEPWYGIEOEYTLLOKDVOWPIGWPVGGF EGEZLV1205F09.g AIFKDPFRGGNNILVICDTYTPAGEPIPTNKRARAAEIFSNQKVINEVPWYGIEQEYTLMQTNVQWPLGWPVGGY A. thaliana AIFKDPFRRGNNILVMCDAYTPAGEPIPTNKRHAAAEIFANPDVIAEVPWYGIEQEYTLLQRDVNWPLGWPIGGF G. $\max$ AIFRDPFRRGNNILVICDAYTPAGEPIPTNKRHAAAKVFSHPDVVAEVPWYGIEQEYTLLQKDIQWPLGWPVGGF

I sativa AIFKDPFRRGNHILVMCDAYTPAGEPIPTNKRAAAAKIFSNPEVEKEVTWYGIEOEYTLLOKDTNWPLGWPLGGF N. tabacum AIFKDPFRRGNNILVICDCYTPAGEPIPTNKRHSAAKIFSHPDVVVEEPWYGLEQEYTLLQKDINWPLGWPLGGF $R$.sativus AIFKDPFRRANNILVMCDAYTPAGEPIPTNKRHAAAKVFSQPDVVAEVPWYGIEQEYTLLQKDVKWPVGWPIGGF

O. sativa AIFKDPFRRGDNILVMCDCYTPQGEPIPTNKRHSAAKIFSHPDVVAEVPWYGIEQEYTLLQKDVNWPLGWPVGGF

Z .mays AIFKDPFRRGNNILVMCDCYTPAGEPIPTNKRYSAAKIFS SPEVAAEEPWYGIEQEYTLLOKDTNWPLGWPIGGF ruler $\ldots 80 \ldots \ldots \ldots 90 \ldots \ldots 100 \ldots \ldots 110 \ldots \ldots 120 \ldots \ldots 130 \ldots \ldots 140 \ldots \ldots$ EGEQRT3001F12.b PGPQGPYYCGVGADKALGRDIVDSHYKACLYAGINISGINGEVMPGQWEFQVGPAVGISAGDELWVARYILERIT EGEZLV1203B04.g PGPQGPYYCGAGADKAFGRDIVDAHYKACLYAGINVSGINGEVMPGQWEFQVGPSVGISASDELWVARYILERIT EGBGFB1211H06.g PGPQGPYYCGVGADKAFGRDIVDAHYRACLYAGINISGINGEVMPGQWEFQVGPAVGISAADQVWVARYILERIT EGEZLV1205F09.9 PGPQGPYYCGVGADKSFGRDISDAHYKACLYAGINISGTNGEVMPGOWEYOVGPSVGIEAGDHIWCSRYLLERIT

A.thaliana PGPQGPYYCSIGADKSFGRDIVDAHYKASLYAGINISGINGEVMPGQWEFQVGPSVGISAADEIWIARYILERIT G.max PGPQGPYYCGVGADKAFGRDIVDAHYKACIYAGINISGINGEVMPGQWEFQVGPSVGISAGDEIWAARYILERIT

L.sativa PGPQGPYYCGIGADKAFGRDIVDAHYKACLYAGVNISGINGEVMPGQWEFQVGPSVGIAAADQIWVARYILERIT

N tabacum PGPOGPYYCGIGAGKVFGRDIVDSHYKACLYAGINISGINGEVMPGOWEFOVGPSVGISAADELWAARYILERIT R.sativus PGPQGPYYCGVGADKSFGRDVVDAHYKACLYAGINISGINGEVMPGQWEFQVGSAVGISAGDEIWVARYILERIT

0. sativa PGPQGPYYCAAGAERAFGRDIVDAHYKACIYAGINISGINGEVMPGQWEFQVGPSVGIAAADQVWVARYILERVT $\mathrm{Z}$.mays PGPQGPYYCGIGAEKSFGRDIVDAHYKACLYAGINISGINGEVMPGQWEFQVGPSVGISSGDQVWVARYILERIT

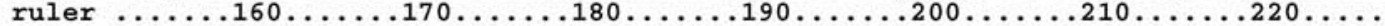

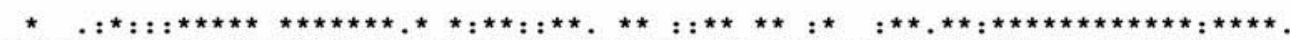
EGEQRT3302E01.g EIAGIVLSFDPKPIQGDWNGAGAHTNYSTKSMRSDGGYEVIKKAIEKLGLKHKEHIAAYGEGNERRLTGRHETAD EGEQRT $3001 \mathrm{~F} 12$.b EIADVVLSFDPKPIQGDWNGAGAHTNYSTKSMRNEGGYEI IKKAIEKLGLRHKEHIAAYGEGNERRLTGRHETAD EGEZLV1203B04.g EIAGVVLSFDPKPIOGDWNGAGAHTNYSTKSMRNEGGYEI IKKAIEKLGLRHKEHIAAYGEGNERRLTGRHETAD EGBGFB $1211 \mathrm{H} 06 . \mathrm{g}$ EIAGVVLTFDPKPIKGDWNGAGAHTNYSTKSMREHGGLNVIKKA IEKLGLRHKHHIAAYGEGNERRLTGRHETAD EGEZLV1205F09.g EQTGVVLTLDPKPIEGDWNGAGCHTNYSTKSMREEGGFEVIKKAILNLSLRHKEHISAYGEGNERRLTGKHETAS A. thaliana EIAGVVVSFDPKPIPGDWNGAGAHTNYSTKSMREEGGYEIIKKAIEKLGLRHKEHISAYGEGNERRLTGHHETAD G. $\max$ EIAGVVVSFDPKPIKGDWNGAGAHTNYSTK SMREDGGYEVIKAAIDKLGRKHKEHIAAYGEGNERRLTGRHETAD L.sativa EIYGVVVSFDPKPIPGDWNGAGAHTNYSTKTMREEGGYEVIKKAIEKLGLRHKEHIAAYGEGNERRLTGRHETAD N. tabacum EIAGVVVSFDPKPIPGDWNGAGAHTNYSTKSMRNEGGYEVIKKAIENLGLRHKEHIAAYGEGNERRLTGRHETAD $R$. sativus EIAGVVVSFDPKPIPGDWNGAGAHCNYSTKSMREDGGYEI IKKAIDKLGLRHKEHIAAYGEGNERRLTGHHETAD

0.sativa EVAGVVLSLDPKPIPGDWNGAGAHTNFSTKSMREPGGYEVIKKAIDKLALRHKEHIAAYGEGNERRLTGRHETAD Z .mays EIAGVVVTFDPKPIPGDWNGAGAHTNYSTESMRKEGGYEVIKAAIEKLKLRHKEHIAAYGEGNERRLTGRHETAD

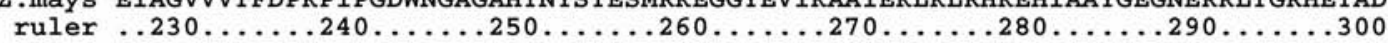
EGEZLV1203B04.g INTFKWGVANRGAS IRVGRDTEKDGKGYFEDRRPASNMDPYVVT SMIAETT ILWKP EGBGFB1211H06.g INTFSWGVANRGASIRVGRDTEKDGKGYFEDRRPASNMDPYVVTSMIAETTILLKP-EGEZLV1205F09.g INTFSWGVANRGCSIRVGRDTEKOGKGYLEDRRPASNMDPYIVTSLLAETTLLWEP - -

A. thaliana INTFLWGVANRGAS IRVGRDTEKEGKGYFEDRRPASNMDPYVVT SMIAETTLLWNPG. $\max$ INTFLWGVANRGASVRVGRDTEKAGKGYFEDRRPASNMDPYVVTSMIADTTILWKP - L.sativa INTFLWGVANRGAS IRVGRDTEKEGKGYFEDRRPASNMDPYVVT SMIAETTILWDNKS N. tabacum INTFKWGVANRGAS IRVGRDTEREGKGYFEDRRPASNMDPFVVT SMIAETTILSEP - $R$,sativus INTFLWGVANRGAS IRVGRDTEKEGKGYFEDRRPASNMEPYIVT SMIAETTILWNP - -

O.sativa INTFKWGVANRGASIRVGRDTEKEGKGYFEDRRPASNMDPYVVTGMIAETTLLWKQN$\mathrm{Z}$.maYs INTFSWGVANRGASVRVGRETEQNGRGYFEDRRPASNMDPYVVTSMIAETTIVWKP - -

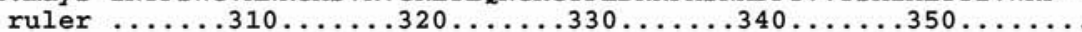




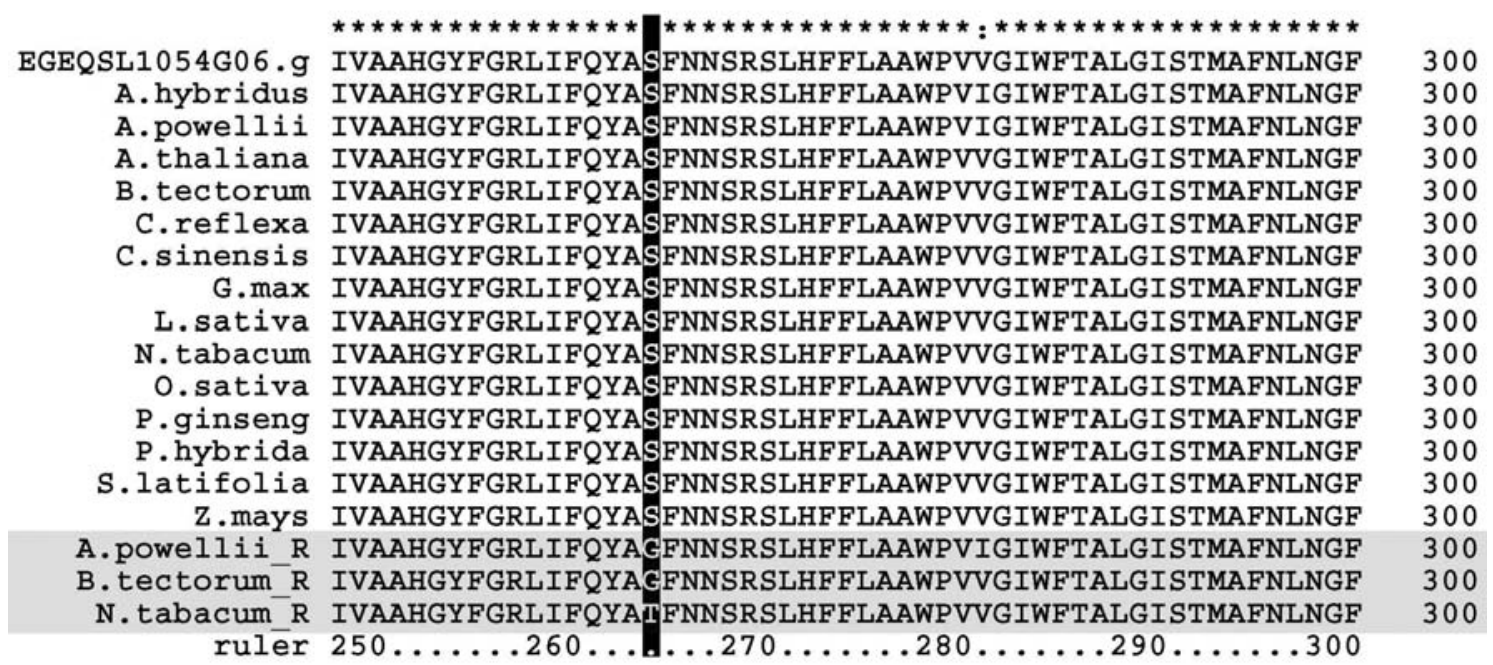

Figure 2 - Alignment of sequences of Protein D1 from different higher plant species.

Table 4 - Translation frames for the nucleotide sequence of the cluster EGEQSL1054G06.g, e-values for the alignments, amino acid sequence lengths corresponding to D1 protein of different higher plant species and identity percentages in relation to the sequence of the cluster.

\begin{tabular}{|c|c|c|c|c|c|}
\hline Species & Frame & g.i. & e-value & Length of sequences ${ }^{(1)}$ & Identity (\%) \\
\hline Amaranthus hybridus & +2 & 131237 & 0.0 & 353 & 95 \\
\hline Amaranthus powellii & +2 & 16119014 & 0.0 & 348 & 94 \\
\hline Arabidopsis thaliana & +2 & 515374 & 0.0 & 353 & 95 \\
\hline Bromus tectorum & +2 & 53828145 & 0.0 & 353 & 95 \\
\hline Cuscuta reflexa & +2 & 400881 & 0.0 & 353 & 95 \\
\hline Camellia sinensis & +2 & 51234109 & 0.0 & 353 & 95 \\
\hline Glycine Max & +2 & 34398494 & 0.0 & 353 & 94 \\
\hline Lactuca sativa & +2 & 16755684 & 0.0 & 97 & 95 \\
\hline Nicotiana tabacum & +2 & 11762 & 0.0 & 353 & 95 \\
\hline Oryza sativa & +2 & 50946439 & 0.0 & 353 & 95 \\
\hline Panax ginseng & +2 & 52220790 & 0.0 & 353 & 95 \\
\hline Petunia hybrida & +2 & 131253 & 0.0 & 353 & 95 \\
\hline Silene latifolia & +2 & 62149327 & 0.0 & 353 & 96 \\
\hline Zea mays & +2 & 902201 & 0.0 & 353 & 95 \\
\hline Amaranthus powellii ${ }^{(2)}$ & +2 & 16904362 & 0.0 & 349 & 94 \\
\hline Bromus tectorum $^{(2)}$ & +2 & 53828147 & 0.0 & 353 & 94 \\
\hline Nicotiana tabacum $^{(2)}$ & +2 & 4589848 & 0.0 & 353 & 95 \\
\hline
\end{tabular}

${ }^{(1)}$ Number of coded amino acids. ${ }^{(2)}$ Resistant to photosystem II inhibiting herbicides.

produce plants with different photosynthetic efficiency and levels of sensitivity to herbicides, it is important to carry out new researches aiming to find Eucalyptus plants with different sequences of the protein. The maternal inheritance facilitates the fixation of desirable characteristics and the use of favorable genes in breeding programs. The presence of long conserved regions will be quite helpful to make up the primers required to study specific regions of the Protein D1.

\section{Acknowledgments}

We would like to acknowledge RIPASA S.A. Celulose e Papel, DURATEX, Votorantim Celulose e Papel, Suzano/Bahia Sul and FAPESP (Fundação de Amparo a Pesquisa do Estado de São Paulo) by the financial support.

\section{References}

Altenburger R, Callies R, Grimme LH, Leibfritz D and Mayer A (1995) The mode of action of glufosinate in algae: The role 
of uptake and Nitrogen assimilation pathways. Pestic Sci 45:305-310

Altschul SF, Madden TL, Schaffer AA, Zhang J, Zhang Z, Miller W and Lipman DJ (1997) Grapped BLAST and PSIBLAST: A new generation of protein data base search programs. Nucleic Acids Res 25:3389-3402.

Alves E, Velini ED, Trindade MLB, Catâneo AC, Marino CL, Mori ES, Guerrini IA, Furtado EL and Wilcken CF (2005) Eucaliptus ESTs related to genes for oxidative Stress. Journal of Environmental Science and Health Part B - Pesticides, Food and Agricultural Wastes B40:16-24.

Arnaud L, Taillandier G, Kaouadji M, Ravanel P and Tissut M (1994) Photosynthesis inhibition by phenylureas: A QSAR approach. Ecotoxicol Environ Safety 28:121-133.

Baron AC, Tobin AK and Wallsgrove RM (1994) The kinetics of azaserine and phosphinothricin inhibition of glutamate synthase cycle enzymes from barley leaves. Plant Physio Biochem 32:555-560.

Baron AC, Tobin TH, Wallsgrove RM and Tobin AK (1994a) A metabolic control analysis of the Glutamine synthetase/ Glutamine synthetase cycle in isolated barley (Hordeum vulgare L.) chloroplasts. Plant Physiol 105:415-424.

Bridges DC and Hess D (2002) Glufosinate: Use and mode of action. In: Herbicide Action Course. Purdue University, West Lafayette. pp 477-486.

Downs CG, Christey MC, Maddocks JFS and Stevenson DG (1994) Hairy roots of Brassica napus: I. Applied glutamine overcomes the effect of phosphinothricin treatment. Plant Cell Reports 14:37-40.

Egner U, Gerbling KP, Hoyer GA, Kruger G and Wegner P (1996) Design of inhibitors of Photosystem II using a model of the D1 protein. Pestic Sci 47:145-158.

Fuerst EP and Norman MA (1991) Interaction of herbicides with photosynthetic electron transport. Weed Sci 39:458-464.
Giardi MT, Rigoni F and Barbato R (1992) QB site modification and the binding of photosystem 2 directed inhibitors during photoinhibition. Photosynthetica 27:173-782.

Hess FD (2000) Light dependent herbicides - An overview. Weed Sci 48:160-170.

Huppatz JL (1996) Quantifying the inhibitor-target site interactions of photosystem II herbicides. Weed Sci 44:743-748.

Itoh S and Iwaki M (1989) New herbicide-binding site in the photosynthetic electron transport chain. Competitive herbicide binding at the phososystem I phylloquinone-(vitamin K)-binding site. FEBS letters 250:441-447.

Judson PN and Rowson GP (1989) Understanding the site of actions of photosystem II inhibitors. Pestic Sci 27:327-334.

Kishi JKU and Ishisuka K (1992) Effect of glufosinate on Glutamine Synthetase isozymes from several plant species. Weed Res (Tokyo) 37:276-282.

Schwartz D, Alijah R, Nussbaumer B, Pelzer S and Wohlleben W (1996) The peptide synthetase gene phsA from Streptomyces viridochromogenes is not juxtaposed with other genes involved in nonribosomal biosynthesis of peptides. J Appl Environ Microbiol 62:570-577.

Thill D (2002) Herbicide resistance in crops. In: Herbicide Action Course. Purdue University, West Lafayette, pp 535-558.

van Rensen JJS (1982) Molecular mechanism of herbicide action near Photosystem II. Physiol Plant 54:515-521.

Weller SC (2002) Photosystem II Inhibitors. In: Herbicide Action Course. Purdue University, West Lafayette, pp 127-80.

Weller SC (1997) Photosystem II Inihibitors. In: Herbicide Action Course. Purdue University, West Lafayette, pp 101-29.

White J, Chang SY and Bibb MJ (1990) A cassette containing the bar gene of Streptomyces hygroscopicus: A selectable marker for plant transformation. J.Nucleic Acids Res. 18:1062-1062.

Associate Editor: Luis Eduardo Aranha Camargo 